(C) The Author(s), 2021. Published by Cambridge University Press on behalf of the British Institute at Ankara. This is an Open Access article, distributed under the terms of the Creative Commons Attribution-NonCommercial-NoDerivatives licence (http://creativecommons.org/licenses/by-nc-nd/4.0/), which permits non-commercial reuse, distribution and reproduction in any medium, provided the original work is unaltered and is properly cited. The written permission of Cambridge University Press must be obtained for commercial reuse or in order to create a derivative work.

\title{
The closing formula of the Old Phrygian epitaph B-07 in the light of the Aramaic $K A I$ 318: a case of textual convergence in Daskyleion
}

\author{
Bartomeu Obrador-Cursach \\ University of Verona, Italy \\ minoricense@gmail.com
}

\begin{abstract}
After an overview of the multilingual epigraphy of Daskyleion during the Achaemenid period, this paper focuses on the closing formula shared by the Aramaic KAI 318 and the Old Phrygian B-07 epitaphs, which consists of a warning not to harm the funerary monument. Comparison of the two inscriptions sheds light on the cryptic Old Phrygian B-07, the sole Old Phrygian epitaph known. As a result, the paper provides new Phrygian forms, like the possible first-person singular umno=tan, 'I adjure you', and a new occurrence of the Phrygian god Ti-, 'Zeus', together with a second possible occurrence of Devos, 'God', equated to Bel and Nabu of the Aramaic inscription.
\end{abstract}

\section{Özet}

Akhamenid döneminde Daskyleion'un çok dilli epigrafisine genel bir bakıştan sonra, bu makale Aramice KAI 318 ve eski Frig B-07 yazıtları tarafından paylaşılan ve mezar anıtına zarar vermeme uyarısından oluşan kapanış formülüne odaklanmaktadır. İki yazııı karşılaştırılması, bilinen tek eski Frig yazıtı olan şifreli eski Frig B-07’ye ışık tutmaktadır. Sonuç olarak, bu makale yeni frig formlarını ortaya koymaktadır: olası birinci tekil umno=tan, 'sana yalvarıyorum', Frig tanrısı Ti-, 'Zeus'un yeni bir oluşumu ve ayrıca Aramice yazıtın Bel ve Nabu'suna eşit olan ikinci olasılık Devos, 'Tanrı' oluşumu gibi.

$\mathrm{T}$ he New Phrygian inscriptions (first to second century AD) are mainly curses attached to Greek epitaphs. However, in the Old Phrygian subcorpus we find a totally different situation: among 402 inscriptions only one epitaph has been identified. This is inscription B-07, found in Daskyleion and dated to the Achaemenid period. It has been suggested by Claude Brixhe (2004: 73) that inscription B06 also contains a funerary text rather than a dedication (as in Bakır, Gusmani 1991), but this fragmentary inscription still eludes interpretation and its nature remains unclear. The epigraphic funerary tradition of the Phrygians prior to B-07 is restricted to personal names incised on bronze, lead and silver artefacts used during funerary banquets inside tumuli and, in the case of the Gordion MM tumulus, on a beam (G346). Therefore, B-07 stands as the sole Old Phrygian epitaph. It is not surprising that this new type of text occured for the first time on the periphery of the Phrygian epigraphic territory and in the last period of Old Phrygian production.
In the following pages I will endeavour to show how these two features impel us to understand B-07 as a textual borrowing from another epigraphical tradition at a time of multiple contacts in Anatolia.

Daskyleion (modern Ergili) was a multicultural city where various cultures and languages came together after the establishment of the satrapal seat of Hellespontic Phrygia by Xerxes I in $477 \mathrm{BC}$ in the context of the threat posed by the Delian League. This important site was rediscovered in 1952 and is still being excavated by the Daskyleion Kazıları (Daskyleion Excavation Project). For the period between the designation of Artabazos as the first satrap and the Macedonian conquest (330 BC), archaeologists have found inscriptions written in Old Persian, Late Babylonian, Aramaic, Lydian, Greek and Phrygian. It must be said that all of these were new incomers to the area and we simply do not know what was the autochthonous language. A suitable candidate is Mysian, but, unfortunately, we have no 
information about this unattested language. It is sometimes connected to the Anatolian branch of the Indo-European language family and said, specifically, to be 'closely related to Lydian' (Simon 2018: 381; following Yakubovich 2010: 115-17, 157; contra Schwertheim 2000: 608). Leaving aside Strabo's report of Mysian as 'half-Lydian and halfPhrygian' (12.8.3), the available data are restricted to onomastics and the attribution of $\sigma \mu$ ív $\theta$ os, "domestic mouse', to the Mysians following the scholia to Aeschylus, where a secondary attribution after Apollo's epithet $\Sigma \mu \nu v \varepsilon \varepsilon \varsigma_{\varsigma}$ read in Homer cannot be ruled out. Note that it is also reported to be a Cretan word (see, e.g., Scholia in Iliadem (scholia vetera) 1.39). Moreover, in 1932, Courtney M. Cox and A.J. Douglas Cameron published an inscription from Üyücek considered to be written in this language, but it is now accepted to be Phrygian (see Brixhe 2004: 32-42 no. B-04; followed by Obrador-Cursach 2020a: 439).

The presence of Old Persian in the city is restricted to 20 fragments of bullae containing the text 'I am Xerxes the king', while Babylonian only occurs in one of these fragments, where the text is bilingual (first published in Balkan 1959; re-examined by Kaptan 2002; 2013; now easily consulted online: Röllig 2017). There is also a bulla written in Greek, but only three letters stand. According to

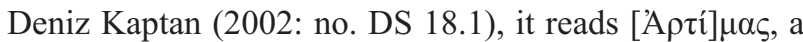
personal name with parallels in Greek, Lycian and Aramaic (see Vernet 2016, with a suggestion of a double origin). Despite the fragmentary nature of the text and the assumption of a dextrorse sigma, this reading has the advantage that a satrap with this name is attested in Lydia by Xenophon in his Anabasis (7.8.25). Greek also occurs in ten graffiti on pottery, mainly Attic and Corinthian importations (Coşkun 2005). We can find, for instance, a probable personal name of an owner, A A $\pi$ ó $\lambda \omega[\nu \mathrm{v}(\mathrm{o \zeta})]$ (S 230, better than the god Apollo), and, perhaps, the advertising claim

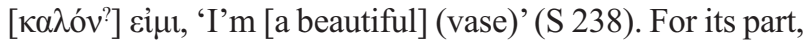
Lydian occurs only in a graffito on a plate consisting of three letters (Bakır, Gusmani 1993: 138 no. 4).

Aramaic is perhaps the most recorded language in Daskyleion for this period. This is coherent with the administrative importance of the city and, as in the case of Old Persian and Babylonian, Aramaic occurs on bullae. There are at least 12 fragments of bullae with different texts (DS 16, DS 18.1, DS 18.2, DS 19, DS 23, DS 24, DS 61, DS 65, DS 70, DS 76, DS 112 and DS 135: see Röllig 2017); these are basically personal names such as mhybwzn (DS 16, considered Iranian by Röllig 2017). A disputed inscription is DS 18, found on two bullae (DS 18.1 and DS 18.2): lsgry or $l s g d y$. The reading of the fourth letter is quite equivocal: it could be resh or dalat (both letters are almost identical in this period), and the identification of the personal name following the preposition $l$, 'belonging to', depends on the choice of reading.
Wolfgang Röllig (2017; followed by Benvenuto 2016: 32; Benvenuto, Pompeo 2017: 35) prefers the reading $s g d y$, and analyses this name as a nisba-formation *sugdya-, 'Sogdian', like other personal names of analogous origin (nysy, 'Nisaean'; [kshy], 'man from [Kush]'). A second reading is offered by André Lemaire (2001: 33), who prefers the reading with resh. After this reading, the name is automatically compared with $\Sigma \alpha \gamma \alpha \rho ı \varsigma, \Sigma \alpha \gamma \alpha \rho ı \varsigma$ and $\Sigma \alpha \gamma \gamma \alpha \rho ı$ s, a personal name well attested in Greek inscriptions from Galatia and Phrygia. Note that the name is also attested as $\Sigma \alpha \gamma \alpha \rho t o \zeta$ and $S G R$ in the Greek-Aramaic bilingual from Faraşa, Cappadocia (Lipiński 1975: 17384 ), commemorating that the man with this name became a magus. A third occurrence of sgry in Aramaic is found in the Elephantine papyri (TAD C3.15:72, 64). It has been argued that, despite a probable metathesis, this name is the same as that found in Old Phrygian as saragis in B-108 and $\mathrm{M}-101$, the former was also found in Daskyleion and followed by the title mago? [s] (Obrador-Cursach 2020a: 340-41; see also Oreshko 2019: 224).

This said, the most famous Aramaic text from Daskyleion (found in Aksakal, close to the city, and first edited by André Dupont-Sommer in 1966) is the epitaph KAI 318 (Daskyleion I in Lemaire 2001). This inscription (fig. 1), dated to the second half of the fifth century BC, was engraved on a Graeco-Persian stele (Istanbul Archaeological Museum 5763) depicting a banquet scene, a common representation of the period. Since it is important for the interpretation of the Phrygian B-07, I reproduce here the entire text and translation offered by André Lemaire (2001: 21-26):
Plh șlmh zy Plnp br P̌̌y
hw Sbd lnpšh hwmytk
bl wnbw zy ?rḥ? znh
yhwh Sdh ?yš ?l yৎml
1. Ceci (est) le bas-relief d'Elnaf fils d'Ashay.
2. Lui-même a fait sa stèle funéraire. Je t'adjure
3. par Bel et Nébô, toi qui passerais ce chemin,
4. que personne ne (lui) fasse de mal!

English translation: 'This is the bas-relief of Elnaf, the son of Ashay. He himself made his funerary stele. I adjure you by Bel and Nabu, you who would pass the road, let nobody do harm!'

It is worth considering some divergences in the interpretations of prior editors: line 1 Plh șlmh, 'these images' (Cross 1966: 8; Lipiński 1975: 151-52), instead of Lemaire's 'bas-relief'; line 4 yhwh $9 d h$, 'passes by' (Cross 1966: 9) and '(who) will be going' (Lipiński 1975: 151), instead of '(toi qui) passerais'/'you who would pass' (in fact, Aramaic $y h w h$ is a third-person singular: see table 1). 


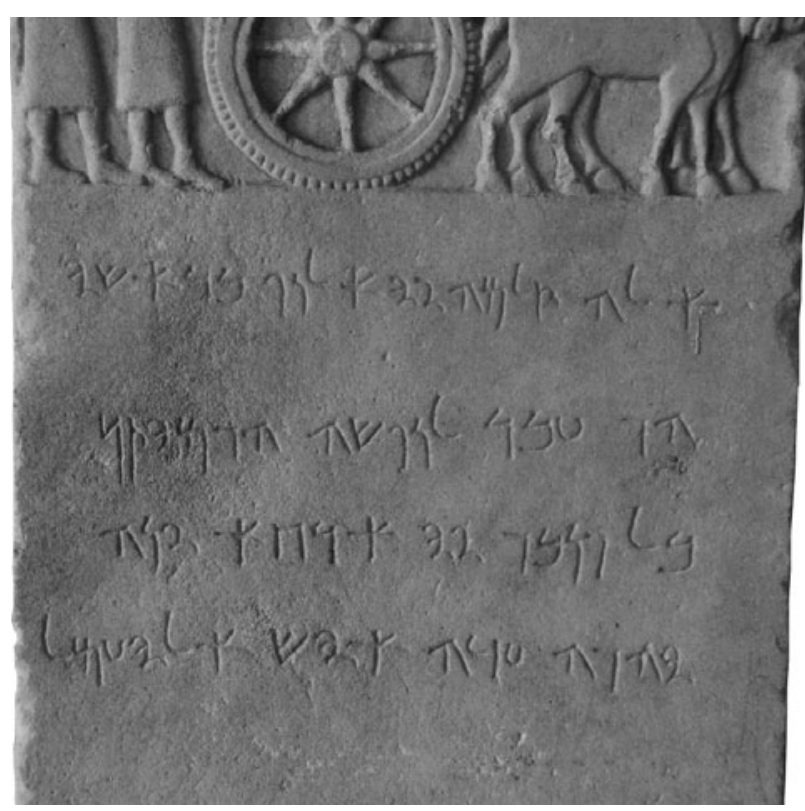

Fig. 1. Detail of the Aramaic inscription KAI 318 (C) Livius.org; Jona Lendering; CC BY-NC-SA 4.0).

A second epitaph from Daskyleion was published by R. Altheim-Stiehl and M. Cremen in 1985. This text is more conventional than the first one, but the stele on which it was engraved is surprising: it is a door-stone, a very specific western Anatolian type of tomb. These first appeared in Lydia at the beginning of the Achaemenid period before spreading to Phrygia in Hellenistic and Roman Imperial times, where it became one of the most characteristic types of sepulchres. This Aramaic text on a western Anatolian funerary stele shows perfectly how different cultures coexisted in this city. A third funerary stele with an Aramaic inscription, again of the GraecoPersian type, was found in Sultaniye Köy, not far from Daskyleion (Altheim-Stiehl et al. 1983).

Leaving aside the two aforementioned Phrygian inscriptions on stone (B-06 and B-07), eight Phrygian graffiti on pottery have been recovered from this site: three on two Attic cups and one kantharos (B-101-03), three on an amphora (B-104-06), one on a Mysian plate (B-107) and one on a bowl (B-108). As noted above, all these languages were incomers to this region, so the linguistic assemblage of the city may be increased by at least one if we include the possible autochthonous language.

Having looked briefly at the five languages attested in Daskyleion, we might consider whether there is evidence of interactions between them. Because of the nature of the records, it is difficult to answer this question in any depth. However, I will try to show that at least the Aramaic inscription KAI 318 and Phrygian B-07 share the same closing formula. Note that the identification of indirect bilinguals in Phrygian has been very productive for deci- phering the Phrygian. Anna Elisabeth Hämmig (2019: 294), for instance, has shown that two New Phrygian curses are shared with Greek inscriptions from Roman Phrygia (same area, same period): compare $\mu \eta \quad \delta \dot{\varepsilon} \gamma \tilde{\eta}$

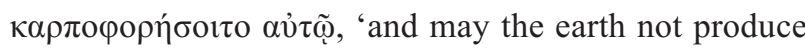

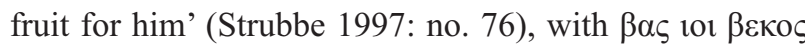
$\mu \varepsilon \beta \varepsilon \rho \varepsilon \tau$, 'let Bas not produce bread for him' (New

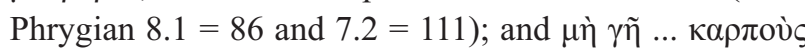

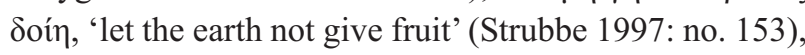

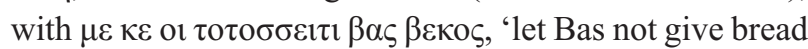
to him' (New Phrygian $7.1=99$ ). Through this comparison, Hämmig has successfully confirmed the prohibitive particle $\mu \varepsilon$ and the root $*$ deh $_{3^{-}}$, 'to give', in the Phrygian

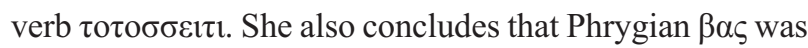
the equivalent of Greek $\gamma \tilde{\eta}$, 'earth', but in ObradorCursach 2017 it is considered an epiklesis of the Phrygian Zeus. To this point, one can add the epithet of Zeus

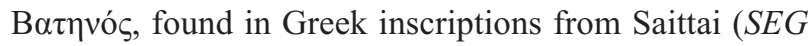
35.1232, 49.1654; TAM 5.1.77). Moreover, Alexander Lubotsky (1998: 420) has compared the Hieroglyphic Luwian curse KARKAMIŠ A $2+3 \S 24 w a / i-s a-{ }^{\prime}$ ' DEUS$n a-z a \quad$ CAPUT-tá-za-ha : *336-na-na : (DEUS)

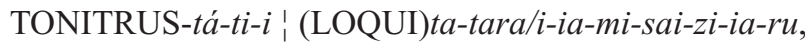
'let him be made accursed by Tarhunt in the sight of' gods and men!' (I must thank Federico Giusfredi for the observation that the Luwian postposition is in fact *336-na-na instead of *366-na-na as quoted elsewhere after the mistake by J.D. Hawkins in his monumental Luwian corpus: 2000: 110, 112), with the common New Phrygian

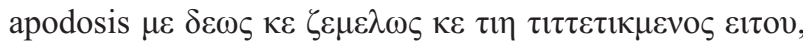
'and let him become accursed by Zeus among gods and men' (passim, standardised). We do not know how this formula survived until the Roman Imperial period, but it

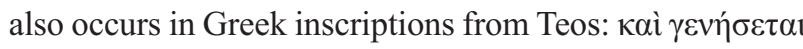

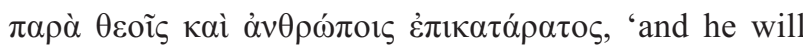
become accursed in the sight of gods and men' (Teos 186). Consequently, this approach has proved useful for deciphering Phrygian.

\section{The Old Phrygian epitaph from Daskyleion B-07: status quaestionis}

The Old Phrygian inscription B-07 (fig. 2) occurs under the relief of a banqueting scene in which a couple in the centre is assisted by three servants (Gusmani, Polat 1999: 137-51). These types of motif, found in two more stelae from Daskyleion (one containing the Aramaic text KAI 318 and the other anepigraphic), are commonly associated with Persian clientele in satrapal centres and show elements of Perso-Anatolian cultural hybridisation with influences of Greek styles (on this point, see Baughan 2013: especially 249-54). Thus the parallels date the artefact to the Achaemenid period, although the stele was found decontextualised during works in a stream bed. 


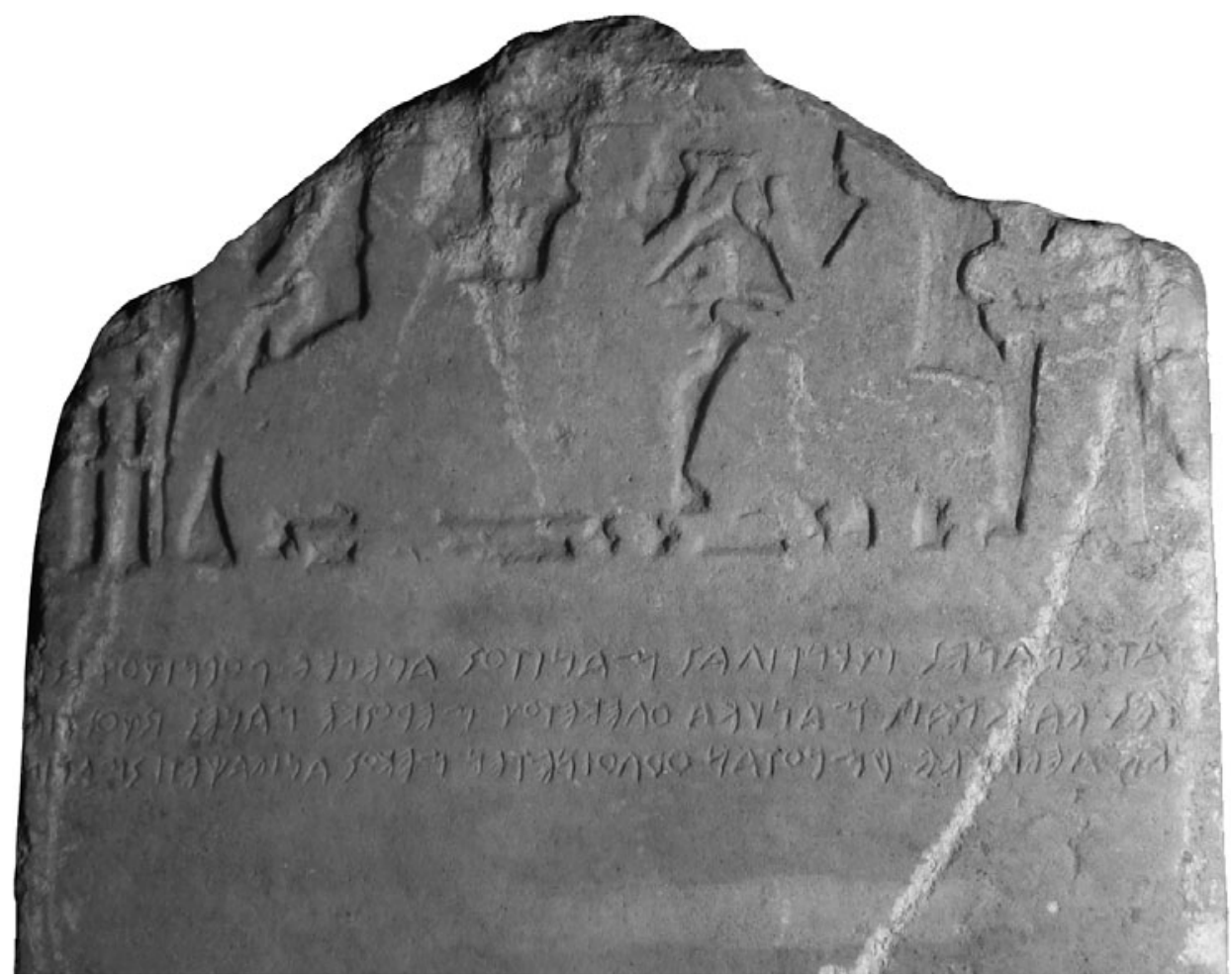

Fig. 2. Top of the stele containing the Phrygian inscription B-07 (courtesy of Alexander Lubotsky and Alwin Kloekhorst).

The text is displayed in three lines written from right to left. It is largely preserved, although both lateral edges are eroded and some letters lost. Luckily, the words are separated by blanks, with the sole exception of clitics (the demonstrative $s=$ and the decopulative $k e$ ), which are attached to a stressed word. In the first line there is also an interpunction consisting of two points. Leaving aside the edges, the reading of the letters is mainly assured after Brixhe's reading (2004: 73-85). Here, I provide the text with segmentations reconsidered in Obrador-Cursach 2020a: 411:

[.]gat : s=manes iyungidas manitos apelev porniyoy esț[..] [..]es va knais manuka odeketoy meros ke manes is yos tiv[.] $[. ?]$ ke devun ke umnotan ordoineten me kos anivaketi s=manin

After a first obscure word [.] gat (without parallels), the first editors (Gusmani, Polat 1999) read in manes iyungidas manitos the identification of the person to whom the funerary monument is devoted. After the demonstrative clitic $s=$, we find the well-known personal name manes (in nominative), the patronymic iyungidas and the papponymic manitos (in fact, the genitive of manes, according to Brixhe 2004: 74; see also Obrador-Cursach 2020a: 82). The only difficulty here is how to analyse iyungidas. According to Brixhe (2004: 77-78; 2006: 401), it may be a patronymic in -ida -, like Greek $-1 \delta \alpha \varsigma /-1 \delta \eta \varsigma$, but this is far from clear. Firstly, the spelling $i y$ - is unique in
Phrygian, the name is unparalleled and, like many of the names borne by Phrygians, it does not appear to be Phrygian, although we do not know its origin. A patronymic in -idas is also unexpected because in Phrygian patronymics are created through the suffix -evais, like arkievais, 'son of Arkhias' (M-01), and, possibly, -iyo- (cf. imeneia tiveia G-193b, feminine). Moreover, -idas cannot be an inherited feature, because of the Phrygian devoicing of the voiced stops (rightly defended by Lubotsky 2004), and a borrowing is not attractive if we consider that these kinds of patronymics never occur in Greek inscriptions. It is true that we have an example of a Greek fossilised patronymic in the Lycian name ipresidah (TL 029, genitive), but this is an original Lycian name *ipresidi hellenised as ' $\mathrm{\mu} \mu \beta \rho \sigma \sigma^{\prime} \delta \eta \varsigma$, a form identical to the Homeric patronymic of Pirithous, secondly reintroduced in Lycian

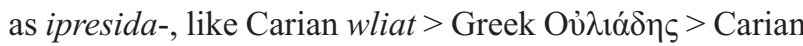
uliade (Adiego Lajara 2011: 329-32). In any case, once a parallel or an origin for the discussed Phrygian form has been identified, it can be considered a name in iyung- (if -ida-s is still accepted as a patronymic morpheme), a name in iyungida- or even an ethnic in $-\bar{a} s<*_{-}-h_{2}-s$, as Old

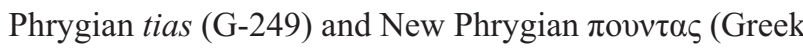

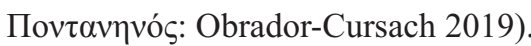

The following words of the first line remain unexplained: apelev porniyoy est [...]|[..]es (see Brixhe 2004a: 79-80 for hypothetical comparisons). We have to move to 
va knais manuka odeketoy to see a clearer sequence. Indeed, va knais, 'his wife' (a possessive followed by a noun), is said of Manukka, a feminine personal name also attested in Persepolis (see Obrador-Cursach 2020a: 293, against an interpretation as 'stele'). This woman, Manes' wife, must be the subject of odeketoy, a verb with a thirdperson middle-voice ending. Although -toy clearly corresponds to such an ending, the meaning and the analysis of the root of this verb are not clear at all: it can be analysed as $o$-dek-e-toy (perhaps derived from PIE $* d^{h} e h_{1^{-}}$, 'to do, put, place' [LIV : 136-38], like New Phrygian active $[\alpha \delta] \delta \alpha \kappa \varepsilon \tau$, ' $[\mathrm{s}]$ he does', passim), if o-dek-e-toy contains $* d^{h} h_{l} k$ - (Brixhe 2004: 80), the zero grade of the root expected for the middle-passive voice in Proto-IndoEuropean, but this is merely a possibility. The alternative od-e-ket-toy, an aorist with augment, would be very suitable but a hypothetical root -ket- remains unidentified in Phrygian (see Simon 2015: 24).

Following the reading, it is unclear what the copulative conjunction ke connects: meros ke manes is. According to Brixhe (2004: 81-82), meros is a second direct object after manuka. However, this interpretation is no longer possible once manuka has been identified as a nominative singular personal name. Following this unclear word, manes occurs again in nominative, but it is difficult to determine what meros and is are. The first word is considered to be the same found in MPhr-01 (W-11) as $\mu 1 \rho \circ$ (nom. sg.) and in New Phrygian 16.1 (116) as $\mu$ ipov (sg. dat.?), but their contexts are not illuminating. On is, Brixhe (2004: 82) considers the presence of the copulative verb: * $h_{1}$ ésti $>*$ est $>$ is; but this is merely a possibility. After this sequence, R. Gusmani identifies yos as the common relative 'who(ever)' and concludes that it refers to the preceding manes (Gusmani, Polat 1999: 150). If this were the case, manes is yos could mean 'Manes is he who ...' (see also Brixhe 2004: 82). On the following fragmented word, the most reliable observation has been offered by Lubotsky, who suggests that $t i v[$.] may contain the root $t i$-, 'Zeus' (Lubotsky 2004: 230). Note however that the copulative conjunctions ... =ke ... =ke (note a mistake in the second ke in Obrador-Cursach 2020a: 411) connect tiv[.] with devun, 'god' (on the alternative reading devu[-]s in Gusmani, Polat 1999: 159, see below). In Phrygian the enclitic copulative conjunction $k e\left(<* k^{u} e\right)$ usually occurs after the word it links, but it can occur twice: after the first and the second element it coordinates. See, for example, New Phrygian: $\mu \varepsilon \delta \varepsilon \omega \varsigma \kappa \varepsilon \zeta \varepsilon \mu \varepsilon \lambda \omega \varsigma \kappa \varepsilon$, 'in the sight of gods and men' $(3.1=97)$. This disposition is the same as found in other Indo-European languages. Compare Phrygian $\kappa \varepsilon$ with its cognates: Sanskrit ca in ahám ca tvám $c a$, 'I and thou' (Rigveda 8.62.11), Greek - $\tau \varepsilon$ in $\pi \alpha \tau \eta े \rho$ $\dot{\alpha} \nu \delta \rho \tilde{\omega} \nu \tau \varepsilon \theta \varepsilon \tilde{\omega} \nu \tau \varepsilon$, 'the father of men and gods' (Iliad 1.544) and Latin -que in noctesque diesque, 'night and day' (Plautus Amphitryon 166). Consequently, ... =ke ... =ke in
B-07 coordinates devun at least with $\left[{ }^{?}\right] n$, if not with $t i v[] \mid.\left[{ }^{?}\right] n$. Indeed, it is very likely that the ending of $t i v[$. is the sequence $\left[{ }^{?}\right] n$ in the following line, as Brixhe

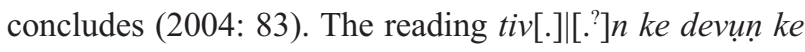
provides two words with the same ending (accusative or genitive plural).

Brixhe considers the word umnotan to be a verbal adjective in -to- in feminine accusative singular (2004: 84). Moreover, he rightly concludes that it may be derived from the verb also attested in the personal forms umniset (B-05)

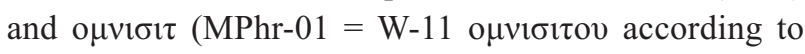
Obrador-Cursach 2020b: 46-48). The word ordoineten is also considered a feminine in -e-, perhaps in agreement.

In the closing words, me kos anivaketi s=manin, I have identified a formula shared with the Aramaic epitaph $K A I$ 318, from Daskyleion (Obrador-Cursach 2020a: 43-45). According to this view, the Phrygian sentence means 'let nobody do harm to Manes', while the Aramaic epitaph ends with ?yš $P l y\{m l$, 'let no one do harm' (see Cross 1966: 8-9). We can find in the Aramaic text the indefinite pronoun $2 y s$, 'someone' (a grammaticalisation of 'man'), as the subject, followed by the negative particle $? l$ and the verb $y$ Gml (3sg. (h)afel imperfective of $\$ \mathrm{ml}$, 'to labour'), with the meaning 'to vex, trouble, disturb' (Hoftijzer, Jongeling 1995: 871). The following analysis is made of the Phrygian words. First, $m e$ is the prohibitive particle

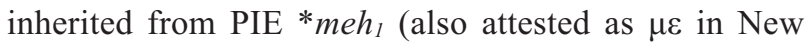
Phrygian $7.1=99,7.2=111,8.1=86,11.2=18)$. The following word, anivaketi (in fact, anivaYeti, but $\langle\Psi\rangle$ is considered a graphic variant of $\langle\mathrm{k}\rangle$ : cf. Obrador-Cursach 2020a: 38-49), is clearly a verb in third-person singular

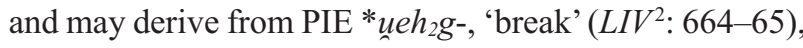

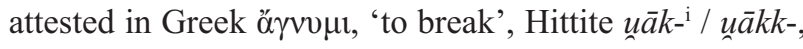
'to bite', and Tocharian A and B wāk-, 'to split, to burst'. It implies that an-may be a preverb parallel to Greek òvó, but the letter ${ }^{\circ} i^{\circ}$ between the preverb and the verbal root remains unexplained. Here there are two possibilities. The Phrygian rendering of the preposition $* h_{2}$ en- may have added a particle $*_{-} i$, as found in prepositions of other languages like Greek $\pi \varepsilon \rho i$ and Sanskrit pári, derived from *per-. Alternatively, this vowel could be a simple epenthesis: there are no instances of a cluster ${ }^{\circ} n v^{\circ}$ in the Phrygian corpus and there is a second instance of an epenthetic /i/ in New Phrygian $\kappa i v o[v] \mid \mu \alpha(22.1=9)$ for

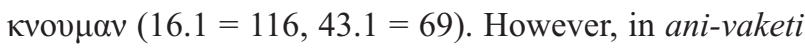
we are dealing with a morpheme boundary and the phonetic conditions are not exactly comparable: an anonymous reviewer remarks that there are no German words containing -mpfn-, but that is no constraint on the word Dampf-nudel, where the morpheme boundary allows the combination to occur. Finally, s=manin is the accusative of manes with the clitic attached as in the first line (see Brixhe 2004: 84-85). 


\section{Expanding the comparison between Aramaic $K A I 318$ and Old Phrygian B-07}

With the current analysis, we understand only a few segments of the inscription. However, the comparison between the Phrygian and the Aramaic closing formulae can be more productive. The Aramaic inscription KAI 318 has two parts. Lines 1-2 are devoted to the circumstances of the monument: the identification of the owner and promotor of the monument and its nature. We can read $P l h$ slmh zy Plnp br P̌sy $\mid h w$ Sbd lnpšh, "these are the images of Elnaf the son of Ašay. He made his funerary stele'. We do not know most details of the first two lines of the Old Phrygian B-07, but it also seems to contain the identification of the deceased (manes iyungidas manitos, line 1) and the promoter of the monument (very likely va knais manuka, 'his wife Manukka', line 2). Although this kind of information is universal in epitaphs, it is only the structure that we can expect to be similar, while the details are particular to each case. In ancient Syria and Anatolia, however, the second part of a monumental inscription is commonly devoted to guaranteeing the preservation of the monument itself and the memory of the people it refers to. For example, in the famous Tell Fakheriye bilingual inscription, written in Neo-Assyrian and Aramaic, a sequence of curses follows the description of the monument, a statue devoted to Hadad by the king Hadadyith' $i$ (ninth century BC). In the Aramaic version (KAI 309) the curses are displayed in lines 16-18, which, according to Krzystof J. Baranowski (2012: 178), read as follows: 16 [...] mn yld šmy mn m?ny? 17 zy bt hdd mr?y mr?y hdd lhmh wmwh ?l ylqh mn 18 ydh swl mr'ty lhmh wmwh tlqh mn $y d h$, '[16] ... Whoever removes my names from the utensils [17] of the temple of Hadad, my lord, may my lord Hadad not accept his bread and his water from [18] his hand (and) may Šawala, my lady, not accept his bread and his water from his hand.' Moving to the Anatolian world, texts of this type are very common on monuments with Hieroglyphic Luwian inscriptions; they are also common in Phrygian (especially from Roman times, with precedents in Old Phrygian like W-01b) and occur in Lydian (e.g. LW 001 lines 3-8) and Lycian (Christiansen 2009) as well as in Greek (Strubbe 1997), even after Christianisation (see Trophimos' ossuary, ca 276-282: Tabbernee 1997: no. 35; see also Floridi 2013). The protecting formula of the monument can consist of curses against desecrators (such as Tell Fakheriye), blessings to readers of the epitaph who also preserve it (see Crawford 1992 for the Semitic tradition) or warnings not to cause harm (like the closing formula of the aforementioned Aramaic inscription from Daskyleion, KAI 318, lines 2-4).

Protecting formulae are easily copied to similar monuments (sometimes with few changes). Indeed, New Phrygian curses are interesting examples because normally the same Phrygian formula shared by a hundred monuments of the same type follows the description of the monument in Greek. As has been seen, the closing formula of the Old Phrygian epitaph B-07 is very similar to the Aramaic one: me kos anivaketi s=manin, 'let nobody harm Manes'. As stated previously (Obrador-Cursach 2020a: 44-45), however, the Phrygian inscription shares more features with the Aramaic one. Because of the presence of yos, B-07 contains a relative sentence and the presence of gods is assured by devun, features shared with the Aramaic inscription $K A I$ 318. The question, then, is if indeed the whole closing formula of KAI 318 can be found in Phrygian as yos tiv[.]|[??] n ke devun ke umnotan ordoineten me kos anivaketi s=manin.

If Phrygian me kos anivaketi s=manin, 'let nobody harm Manes', renders Aramaic Pyš Pl y̧ml, 'let no one do harm', yos tiv[.]|[.?] n ke devun ke umnotan ordoineten may correspond to hwmytk |bl wnbw zy Prh? znh $\mid y h w h$ Sdh, 'I adjure you, by Bel and Nabu, who will cross this road ...'. A first problem is the comparison between the Aramaic gods $b l w n b w$, 'Bel and Nabu', and the sequence $t i v[] \mid.\left[{ }^{?}\right] n$ ke devun ke. As has been noted, Lubotsky considers a possible presence of the root $t i-$, 'Zeus', in $t i v[$.$] , but the$ word must end in the third line. It can be read $t i v[] \mid.[]$.$n or$ $\operatorname{tiv}[] \mid$.$n because the lack of a letter at the beginning of the$ last line is not clear. An easy solution is to restore a vowel, $\operatorname{tiv}[a] \mid n$, and consider it the accusative of the theonym 'Zeus', found in New Phrygian as $\tau \iota \alpha v(2.2=130,7.1=$ $99,7.3=14,16.1=116,46.1=53)$. It implies that the consonantal $v$ in $t i v[a] n<*$ diém (Lubotsky 2004: 230) is not etymological but a mere antihiatic spelling or glide, just like in devụn $<* d^{h} h_{1}$ som (cognate of Greek $\theta \varepsilon o ́ \varsigma$ ). This last word could be analysed either as an accusative singular or a genitive plural, but the connection with $t i v[a] n$ shows that it must be the former. According to this interpretation, tiv[a]n ke devun ke, 'Zeus and the god', renders Aramaic $b l$ wnbw, 'Bel and Nabu'. The comparison between the Phrygian Zeus, the male superior storm god, and the Aramaic $b l$, 'Bel' - its northwestern Semitic equivalent makes sense. An explicit parallel for this syncretism can be found in the Syro-Mesopotamian Zev̀ $\mathrm{B} \tilde{\eta} \lambda$ os (first in Herodotus 1.181.2). A problem, however, is presented by the use of the Phrygian noun for 'god', devun, to render the Aramaic $n b w$, 'Nabu'. This is found in only one other Old Phrygian inscription, P-03, where the noun also refers to a male god after an authority: vasous iman mekas kanutieivaị | devos ke mekas, 'Vasos Iman the great the son of Kanutî and the great god'. Personally, I cannot confirm that devos refers to the same god in P-03 and B-07, but it is possible.

At this point, a cultural comment on the gods $b l=$ $\operatorname{tiv}[a] n$ and $n b w=$ devun is needed. The Aramaic pair of male gods is not unparalleled, and their occurrence in 
Daskyleion can be explained in the light of these testimonies. Nabu ( $n b w$ in the Aramaic sources) appeared at the beginning of the second millennium but became more prevalent in the 14 th century BC. The major spread of the cult of Nabu, however, came with the expansion of the Neo-Assyrian and Neo-Babylonian empires. At an early stage he was identified as the son of Marduk (Millard 1999), the local god of Babylon, who underwent a syncretism with BaSal, the storm god, very likely after the use of BaSal/Bèlu as Marduk's title.

At least from the Hellenistic period, a syncretism between Nabu and Apollo occurred. Research has highlighted the role of this god in the Seleucid dynasty, especially under Seleucus I and his son Antiochus I (Dirven 1999: 145-46; Beaulieu 2014: 19), but it is possible that these monarchs took and appropriated a prior reality. Nabu shares with Apollo a relationship with the arts and prophecy, and it is possible that Apollo's arrow and Nabu's stylus were also connected (Drijvers 1980: 72). Once Zeus was identified with (Marduk-)Bel, their children were easily syncretised too. One can adduce here the view of H.J.W. Drijvers, that expressions such as brmryn Plh?, 'Barmarē (= literally 'the son of our lords') the god', found in inscriptions from Hatra, refer to Nebo/Nabu (1980: 47).

As Drijvers states, Bel occurs as interpretatio Babylonica of local gods who share with him some general features and pre-eminence in worship (1980: 53-54). Nabu, however, seems to be a direct loan, although there may in some cases be a syncretism with a local son god. The couple formed by Marduk (under the name Bel) and Nabu occurs in the Hebrew Bible (Isaiah 46:1) and there are Aramaic testimonies close in time to both occurrences in Daskyleion. For example, in an ostracon from Elephantine (ca sixth to fifth century BC) they appear in a list of gods expected to ensure the welfare of a person in the greeting formula: $b l w n b w \check{s} m \check{s}$ wnrgl, 'Bel and Nabu, Šamaš and Nergal' (Dupont-Sommer 1944 = Porten, Yardeni 1986-1999: D7.30). Two other instances of both gods occurring together can be found on two tesserae from Palmyra (Ingholt et al. 1955: 136, 137). Despite our poor knowledge of the Phrygian pantheon, it makes sense that in Daskyleion the Phrygian storm god, Ti- (the nominative has not yet been identified), was equated to Bel and a local god called De(v)os (literally 'the god') to Nabu, his son in the Semitic system.

At this point, it should be noted that Old Phrygian devun is read as devu[-]s by Gusmani (Gusmani, Polat 1999: 159). Lubotsky, who has examined the inscription in the Bandırma Museum, prefers Gusmani's reading and suggests a possible accusative plural devu[i]s (personal communication July 2020), which goes back to a protoform $* d^{h} h_{I} s$-ó-ns (shared with Greek $\theta \varepsilon o v ́ \varsigma$ ). If he is right, tiv[a]|n ke devun ke may mean 'Zeus and the gods', a sequence similar to New Phrygian 20.3 (=62) $\alpha \tau \tau$ i $\kappa \varepsilon$ $\delta \varepsilon \omega \varsigma \kappa \varepsilon$, 'by Zeus and the gods'. According to this reading and analysis, devu[i]s does not refer to a single god but to all divinities. However, a spelling devu[i]s is unparalleled for this case: other possible thematic accusative plurals are ktevoys, 'properties (?)' (B-01), and patriyiois, 'relatives' or 'paternal (?)' (B-04; see Ligorio, Lubotsky 2018: 1826).

Following the comparison of the two inscriptions from Daskyleion, umnotan and ordoineten may render Aramaic hwmytk, 'I adjure you' (1sg. hafel of ymy, 'swear'), and Prh? znh yhwh $9 d h$, '(who) will cross this road'. This Aramaic part consists of a direct object, a plural demonstrative $(z n h)$ in agreement with a noun (?rh?) and a verbal periphrasis with a durative or iterative meaning (e.g. Muraoka, Porten 1998: 205-06) built with

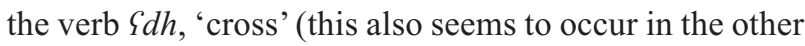
Aramaic inscriptions from Daskyleion: Lemaire 2001: 28 ), and the auxiliary $y h w h$ ( $3 \mathrm{sg}$. imperfective). Brixhe (2004: 84) rightly identifies in umnotan the same verbal

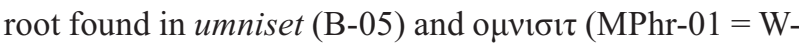

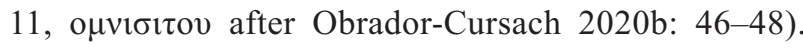
Another possible testimony has been found in Dorylaion (modern Sarhöyük) on a stone fragment dated to the sixth or fifth century BC containing an Old Phrygian inscription which can be labelled as NW-02. The first editors read it as [---] iman ' umnip[---], where iman is the wellknown Phrygian personal name or 'shrine' as in B-05 (a

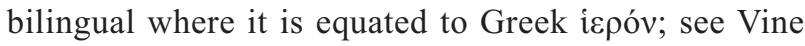
2010 ) and umnip [---] a possible personal name (Baştürk, Avram 2019). Such a name is unparalleled and the sequence $u m n$ - only occurs with the verb forms described here. Therefore, it is easiest to read the last remaining letter as part of an $\langle s\rangle$ with the same shape found, for example, in B-04 (Brixhe 2004: 28), which is not very different from the shape in B-05. If this is so, it is easy to see another form of the same verb, perhaps umnis [et] as in B-05. In any case, the Phrygian verb umn-/opv- goes back to PIE * $h_{3} e m_{3^{-}}$, 'to swear' $\left(L I V^{2}: 265-66\right.$, as $\left.* h_{2} e m h_{3}-\right)$ and is a cognate of Greek ö $\mu v v \mu 1$, 'id.'. In Phrygian, it may mean something similar to 'swear, pray, vow' (see Obrador-Cursach 2020b: 47-48). Consequently, B-07 umnotan is a good candidate to render Aramaic hwmytk, 'I adjure you'. According to Brixhe, it is a verbal adjective in -to- but, syntactically, this adjective remains isolated. In the light of the comparison presented here, it is easier to think that we are dealing with a first-person $u m n o<* o m-n-\bar{o}$, parallel to Aramaic hwmyt, '(I) adjure'. Consequently, the remaining =tan must be a clitic attached to the main verb, very likely a second-person singular accusative, like Aramaic $-k$. If the analysis suggested for B-07 is correct, umno=tan corresponds to Aramaic hwmyt- $k$, 'I adjure you', and, morpho- 
logically, =tan instead of *te may be a levelling from the accusative ending -an of the athematic or $a$-stems. Few enclitics attached to verbs have been identified in the Phrygian corpus. The enclitic $=s$, very likely a nominative masculine singular referring to the subject of the verb (Obrador Cursach 2020b), occurs in Middle Phrygian

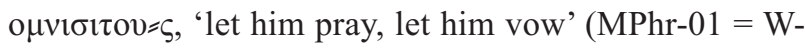
11; in the analysis o $\mu v \imath \sigma ı=00 \varsigma$ by Brixhe 2004: 24 a clitic =ov $\varsigma$ is also needed), and New Phrygian $\tau \varepsilon v \tau o v=\varsigma$, 'let him lack' (two occurrences: $62.2=36$ and $62.5=36$ ). A form tan= occurs attached to a verb in Old Phrygian tan=egertoy (W-01c, Areyastin monument): 'Ataniyen the ruler X-ed you' ('sacrificed to you, adored you', vel sim.?). However, the verb is a hapax and tan= can be analysed alternatively here as the demonstrative *to- in feminine accusative singular: ataniyen $\vdots$ kuryaneyon $\vdots$ ta $\mid n$ egertoy, 'Ataniyen the ruler X-ed it' or 'X-ed her' (the MotherGoddess?).

Finally, ordoineten may render Aramaic Prh? znh yhwh $\zeta d h$, '(who) will cross this road'. At first glance it would appear surprising that four words could be rendered with a single formation in Phrygian. However, it seems that this part of the expression is not exactly the same. Note that Aramaic has a verbal periphrasis, $y h w h$ $S d h$, which could be expressed by an analytic form in Phrygian, such that $P r h ?$ ? $z h$, 'this road', is very likely omitted from the Phrygian inscription. In any case, ordoineten is totally unparalleled in Phrygian, but, as can be seen, a feminine accusative in - $e$ - (as suggested by Brixhe 2004: 84) is not very attractive because the alleged PIE $* \bar{e}$-stems (hypothesised on the basis of Lithuanian nouns in $-\dot{e}$ and the Latin fifth declension, but see Pedersen 1926) would be expected to merge with $a$-stems in Phrygian. The main problem here is the lack of lexical and morphological parallels. Although it does not look like a third-person singular, its subject may be the relative pronoun yos. Leaving aside the parenthetical period (tiv $[a] \mid n$ ke devun ke umnotan), what we have in Phrygian is a correlative structure: the sentence introduced by the relative pronoun is the subject of the verb anivaketi, rendered by the indefinite pronoun kos (table 1). A parallel structure, well

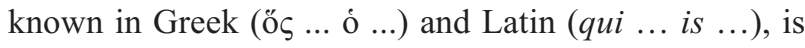
attested in New Phrygian curses with the expected anaphoric $\tau$ os: see, for example, 6.2 (131) $\operatorname{lo} \varsigma v \imath \sigma \varepsilon \mu o v v$

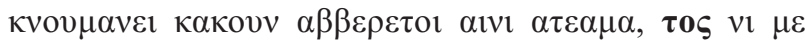

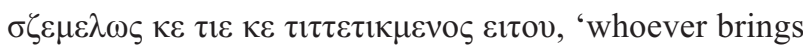
harm to this tomb or to the ateama, let him become accursed in the sight of men and Zeus'. The use of the indefinite pronoun kos in B-07 instead of the anaphoric pronoun $\tau o \zeta$ is in fact surprising and seems to indicate that the formula is a Phrygian formation but a calque: the Aramaic inscription shows the indefinite pronoun $2 y \check{s}$ in the same position.
It is probable that Phrygian ordo- (or ordoi) in ordoineten goes back to a formation $* h_{3} r d^{h}$-uó-, a cognate of Greek ò $\rho$ ós, 'straight'. Although /w/ is preserved in Phrygian, it is assumed to disappear before the vowel /o/.

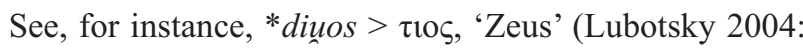
229-30). Formally, ordo could be analysed as an adverb in $-\bar{o}$, just like Greek ov̋ $\tau \omega$, 'in this way or manner, so, thus', or $\tilde{\tilde{\omega}}-\delta \varepsilon$, 'in this wise, thus' (cf. Chantraine 1984: $\S 132$.). However, the lack of blank between ordo ${ }^{\circ}$ and ${ }^{\circ}$ ineten points to a verbal compound. If this assumption is correct, ordoineten may mean something similar to 'go straight'. The root and the ending of the verb remain unidentified. It is possible to see a compound of $i$-, 'to go' ( $<$ PIE * $h_{1}$ ei-, 'id.': $L I V^{2}: 232-33$ ), attested in the imperatives ituv (B-05), Eıนov (New Phrygian passim), 'let him become' $\left(<* h_{l} i\right.$-tu), and ivvov $(28.1=71)$ and $(\alpha \delta) \varepsilon v v v o v$ $(40.1=12)$, 'let them become' $\left(<* h_{l} i-n t u\right)$. In any case, these are mere possibilities that may be confirmed and improved in the future.

Despite the unexplained ordoineten, there are enough similarities to conclude that the closing formulae of Phrygian B-07 and Aramaic KAI 318 contain the same warning. There are, however, some differences: the Aramaic inscription mentions the road where the funerary monument was erected (line 3 Prḥ? znh), while the Phrygian one adds the name of the deceased whom nobody should harm (line 3 s=manin). There are also syntactic differences: in the Phrygian inscription the closing formula begins with the relative pronoun, and between the pronoun and its possible verb ordoineten the parenthetical sentence tiv[a]n ke devun ke umno:tan, 'by Zeus and God, I adjure you', is inserted. Therefore, this part of the inscription can be edited and translated as follows:

yos tiv $[a]-$

$n$ ke devun ke umno:tan ordoineten me kos anivaketi s=manin

'By Zeus and the God I adjure you: who goes straight along, let him not harm Manes'

\section{Conclusion}

Following this study of the closing formula of Old Phrygian B-07, the parallels between this inscription and the Aramaic $K A I 318$ are strong enough to conclude that they share a similar formula (table 2). There are, however, important details to be explained, such as ordoineten, which must be a verb form. In the light of the kind of stele used, Manes, the deceased mentioned in B-07, may have belonged to the Persian clientele class in Daskyleion and have been buried following the new customs, showing his position. This would explain why the promoter of the monument, very likely his wife, needed to borrow epigraphic formulae from other traditions. 

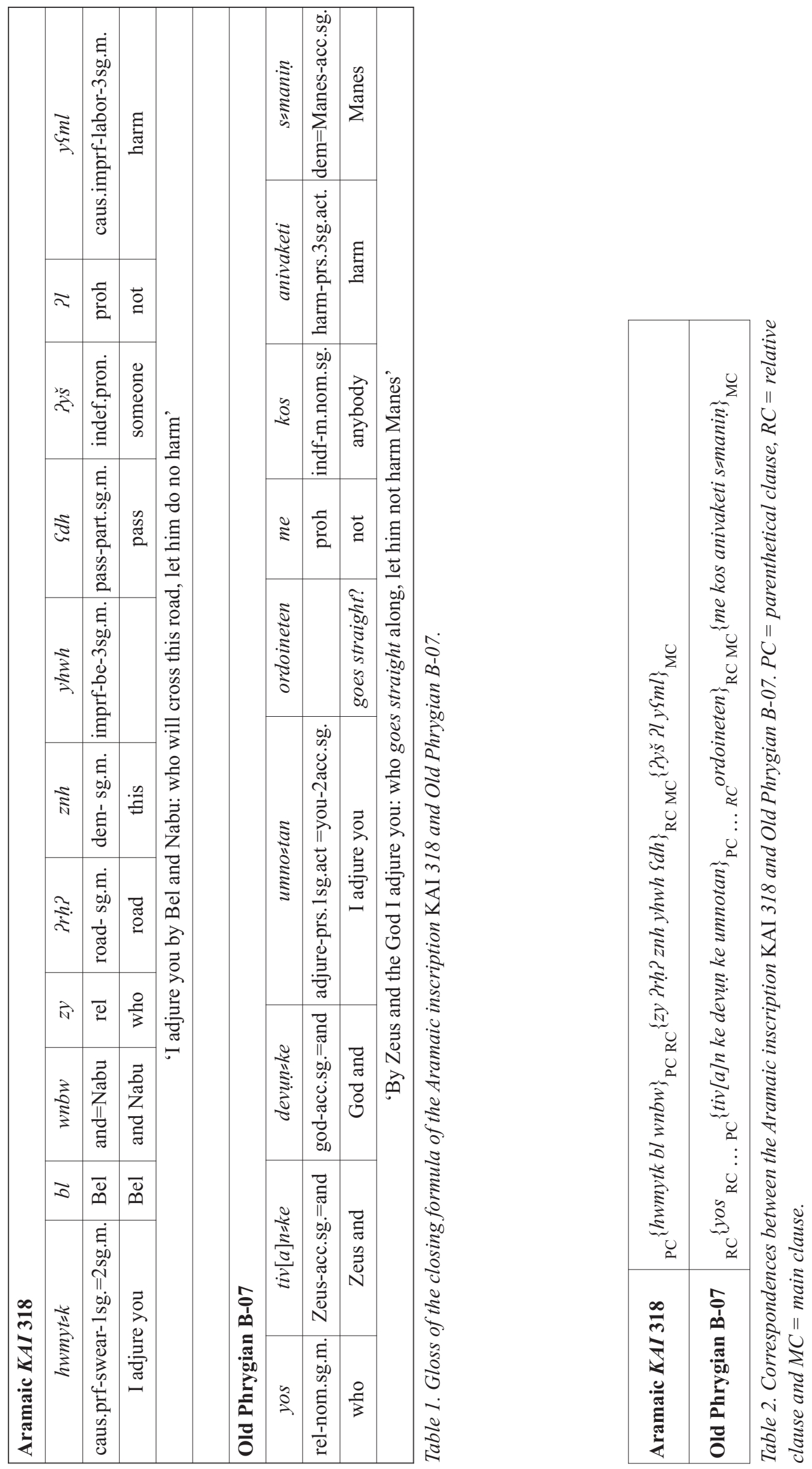


\section{Acknowledgements}

This paper is a product of the project PALaC, which has received funding from the European Research Council (ERC) under the European Union's Horizon 2020 research and innovation programme (Grant Agreement no. 757299). I must thank Diego Corral Varela for his generous explanations of Aramaic. I would like to thank also Federico Giusfredi, Alexander Lubotsky and the anonymous reviewers for their valuable remarks on earlier versions of this paper. Finally, I am in debt to Jona Lendering, Alexander Lubotsky and Alwin Kloekhorst for their generosity in allowing the use of their photos in this article. Needless to say, any mistakes or deficiencies are my own responsibility.

\section{Bibliography}

Abbreviations

$K A I=$ Donner, H., Röllig, W. 2002: Kanaanäische und aramäische Inschriften (5th edition). Wiesbaden, Harrassowitz $L I V^{2}=$ Rix, H. 2001: Lexikon der indogermanischen Verben. Wiesbaden, Reichert

$S E G=$ Hondius, J.J.E., et al. (eds) 1923-: Supplementum epigraphicum graecum. Leiden, Brill

$T A D=$ Porten, B., Yardeni, A. (eds) 1986-1999: Textbook of Aramaic Documents from Ancient Egypt (4 vols). Jerusalem, Hebrew University

TAM = Kalinka, E., et al. (eds) 1901-: Tituli Asiae Minoris. Vienna, Österreichische Akademie der Wissenschaften

Adiego Lajara, I.-X. 2011: "Avatares licios de luvita im(ma)ra/i- "campiña"” in E.R. Luján, J. García Alonso (eds), A Greek Man in the Iberian Street: Papers in Linguistics and Epigraphy in Honour of Javier de Hoz. Innsbruck, Innsbrucker Beiträge zur Sprachwissenschaft: 327-35

Altheim-Stiehl, R., Cremer, M. 1985: 'Eine gräko-persische Türstele mit aramäischer Inschrift aus Daskyleion' Epigraphica Anatolica 6: 1-16

Altheim-Stiehl, R., Metzler, D., Schwertheim, E. 1983: 'Eine neue gräko-persische Grabstele aus Sultaniye Köy und ihre Bedeutung für die Geschichte und Topographie von Daskyleion' Epigraphica Anatolica 1: 1-23

Bakır, T., Gusmani, R. 1991: ‘Eine neue phrygische Inschrift aus Daskyleion' Epigraphica Anatolica 18: 157-64

- 1993: 'Graffiti aus Daskyleion' Kadmos 32: 135-44. https://doi.org/10.1515/kadm.1993.32.2.135

Balkan, K. 1959: 'Inscribed bullae from Daskyleion-Ergili’ Anatolia 4: 123-29. https://doi.org/10.1501/andl_0000000052

Baranowski, K.J. 2012: 'The Old Aramaic and biblical curses’ Liber Annuus 62: 173-201. https://doi.org/10.1484/j.la.5.101306

Baştürk, M.B., Avram, A. 2019: ‘A newly discovered Old Phrygian inscription from Şarhöyük (Dorylaion)’ Ancient West \& East 18: 231-37

Baughan, E.P. 2013: Couched in Death: Klinai and Identity in Anatolia and Beyond. Madison, University of Wisconsin Press

Beaulieu, P.-A. 2014: 'Nabû and Apollo: the two faces of Seleucid religious policy' in F. Hoffmann, K.S. Schmidt (eds), Orient und Okzident in hellenistichser Zeit. Vaterstetten, Brose: 13-20

Benvenuto, M.C. 2016: 'Appunti sulla rappresentazione linguistica dell'identità dell'aristocrazia dominante nella Frigia Ellespontica achemenide' Linguarum varietas 5: 25-38

Benvenuto, M.C., Pompeo, F. 2017: 'Linguistic representations of identity in the Achaemenid world: case studies' in J.A. Álvarez-Pedrosa, M.C. Benvenuto, F. Pompeo (eds), Del Indo al Egeo: relaciones culturales y linguïsticas en el interior del Imperio aqueménida. Madrid, Guillermo Escolar Editor: 17-41

Brixhe, C. 2004: 'Corpus des inscriptions paléo-phrygiennes: supplément II’ Kadmos 43: 1-130. https://doi.org/10.1515/kadm.43.1.1

— 2006: 'Préhistoire et debut de l'histoire des dialectes grecs' Incontri linguistici 29: 39-59

Chantraine, P. 1984: Morphologie historique du grec. Paris, Éditions Klincksieck

Christiansen, B. 2009: ‘Typen von Sanktionsformeln in den lykischen Grabinschriften und ihre Funktionen’ Die Sprache 58: $44-54$

Coşkun, G. 2005: Daskyleion'da Orta Akhaemenid Dönem. PhD thesis, Ege University

Cox, C.W.M., Cameron, A. 1932: 'A native inscription from the Myso-Phrygian borderland' Klio 25: 34-49. https://doi.org/10.1524/klio.1932.25.25.34

Crawford, T.G. 1992: Blessing and Curse in Syro-Palestinian Inscriptions of the Iron Age. New York, Peter Lang

Cross, F.M. 1966: ‘An Aramaic inscription from Daskyleion’ Bulletin of the American Schools of Oriental Research 184: 7-10. https://doi.org/10.2307/1356198

Dirven, L. 1999: The Palmyrenes of Dura-Europos. Leiden/Boston/Cologne, Brill 
Drijvers, H.J.W. 1980: Cults and Beliefs at Edessa. Leiden, Brill

Dupont-Sommer, A. 1944: “Bêl et Nabû, Šamaš et Nergal” sur un óstracon araméen inédit d'Éléphantine' Revue de l'histoire des religions 128.1: 28-39

- 1966: 'Une inscription araméenne inédite d'époque perse trouvée à Daskyléion (Turquie)' Comptes rendus des séances de l'Académie des inscriptions et belles-lettres 110-11: 44-58. https://doi.org/10.3406/crai.1966.11934

Floridi, L. 2013: 'The epigrams of Gregory of Nazianzus against tomb desecrators and their epigraphic background' Mnemosyne 66.1: 55-81. https://doi.org/10.1163/156852511x584973

Gusmani, R., Polat, G. 1999: 'Manes in Daskyleion' Kadmos 38: 137-62. https://doi.org/10.1515/kadm.1999.38.1-2.137

Hämmig, A.E. 2019: 'Deciphering Phrygian: blind alleys and viable ways' in G.R. Tsetskhladze (ed.), Phrygia in Antiquity: From the Bronze Age to the Byzantine Period. Leuven, Peeters: 287-304

Hawkins, J.D. 2000: Corpus of Hieroglyphic Luwian Inscriptions 1: Inscriptions of the Iron Age 1. Berlin, de Gruyter Hoftijzer, J., Jongeling, K. 1995: Dictionary of the North-West Semitic Inscriptions. Leiden/New York/Cologne, Brill Ingholt, H., Seyrig, H., Starcky, J., Caquot, A. 1955: Recueil des tessères de Palmyre. Paris, Geuthner

Kaptan, D. 2002: The Daskyleion Bullae: Seal Images from the Western Achaemenid Empire 1. Leiden, Nederlands Instituut voor het Nabije Oosten

— 2013: 'Déjà vu? Visual culture in western Asia Minor at the beginning of Hellenistic rule' in E. Stavrianopoulou (ed.), Shifting Social Imaginaries in the Hellenistic Period: Narrations, Practices, and Images. Leiden/Boston, Brill: 25-50. https://doi.org/10.1163/9789004257993_003

Lemaire, A. 2001: 'Les inscriptions araméennes de Daskyleion' in T. Bakır (ed.), Proceedings of the First International Symposium on Anatolia in the Achaemenid Period, Bandırma, 15-18 August 1997. Leiden, Nederlands Instituut voor het Nabije Oosten: 21-35

Ligorio, O., Lubotsky, A. 2018: 'Phrygian' in J. Klein, B. Joseph, M. Fritz (eds), Handbook of Comparative and Historical Indo-European Linguistics 3. Berlin/Boston, de Gruyter: 1826-31. https://doi.org/10.1515/9783110542431-022

Lipiński, E. 1975: Studies in Aramaic Inscriptions and Onomastics 1. Leuven, Leuven University Press

Lubotsky, A. 1998: 'New Phrygian metrics and $\delta \varepsilon \omega \varsigma \zeta \varepsilon \mu \varepsilon \lambda \omega \varsigma$ formula' in J. Jasanoff, H.C. Melchert, L. Oliver (eds), Mir curad: Studies in Honor of Calvert Watkins. Innsbruck, Innsbrucker Beiträge zur Sprachwissenschaft: 41321

— 2004: 'The Phrygian Zeus and the problem of the "Lautverschiebung"' Historische Sprachforschung 117: 229-37

Millard, A.R. 1999: 'Nabû' in K. van der Toorn, B. Becking, P.W. van der Horst (eds), Dictionary of Deities and Demons in the Bible. Leiden/Boston/Cologne, Brill: 607-10

Muraoka, T., Porten, B. 1998: A Grammar of Egyptian Aramaic. Leiden/Boston/Cologne, Brill

Obrador-Cursach, B. 2017: 'The Phrygian god Bas' Journal of Near Eastern Studies 76.2: $307-17$. https://doi.org/10.1086/692917

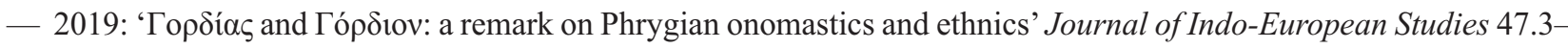
4: 545-52

- 2020a: The Phrygian Language. Leiden/Boston, Brill

— 2020b: 'The last verse of the Middle Phrygian epigram from Dokimeion' Indogermanische Forschungen 125.1: 4149. https://doi.org/10.1515/if-2020-004

Oreshko, R. 2019: 'Phonetic value of Lydian letter $<\mathrm{d}>$ revisited and development of PIE dentals in Lydian' Wekwos 4: 191-262

Pedersen, H. 1926: La cinquième déclinaison latine. Copenhagen, Bianco Lunos

Porten, B., Yardeni, A. 1986-1999: Textbook of Aramaic Documents from Ancient Egypt. Jerusalem, Hebrew University of Jerusalem

Röllig, W. 2017: 'Bullae' in Achemenet. http://www.achemenet.com/en/tree/?/achaemenid-museum/museums-and-institutions/bandirma-archaeological-museum

Schwertheim, E. 2000: 'Mysia' Der Neue Pauly 8: 608-912

Simon, Z. 2015: 'Die letzte Zeile der phrygischen Inschrift von Vezirhan' Acta Classica Universitatis Scientiarum Debreceniensis 51: 17-30

- 2018: 'Anatolian influences on Greek' in Ł. Niesiołowski-Spanò, M. Węcowski (eds), Change, Continuity, and Connectivity: North-Eastern Mediterranean at the Turn of the Bronze Age and in the Early Iron Age. Wiesbaden, Harrassowitz: 376-418. https://doi.org/10.2307/j.ctvckq4zg.3

Strubbe, J.H.M. 1997: APAI EПITYMВIOI: Imprecations against Desecrators of the Grave in the Greek Epitaphs of Asia Minor: A Catalogue. Bonn, Habelt 
Tabbernee, W. 1997: Montanist Inscriptions and Testimonia: Epigraphic Sources for Illustrating the History of Montanism. Macon, Mercer University Press

Vernet, M. 2016: 'The Lycian PN Artimas and Arteimas: a new proposal for an Iranian and epichoric etymology' Glotta 92: 280-94. https://doi.org/10.13109/glot.2016.92.1.280

Vine, B. 2010: 'Old Phrygian iman' in R. Kim, N. Oettinger, E. Rieken, M. Weiss (eds), Ex Anatolia Lux: Anatolian and Indo-European Studies in Honor of H. Craig Melchert on the Occasion on His Sixty-Fifth Birthday. Ann Arbor/New York, Beech Stave Press: 343-55

Yakubovich, I. 2010: Sociolinguistics of the Luvian Language. Leiden/Boston, Brill 